\title{
Incidence of diseases among the pupils of orphanages in different regions
}

\author{
Nakhanova Zhupar' ${ }^{1}$, Kairmukhanova Sholpan ${ }^{1}$ \\ ${ }^{I}$ Referral Center, National research center for maternal \\ and child health of the corporate fund «UMC», Astana, \\ Kazakhstan \\ ${ }^{2}$ Department of pediatrics, Republican diagnostic center \\ of the corporate fund «UMC», Astana, Kazakhstan
}

J CLIN MED KAZ 2017; 3(45 SUPPL 3):139-140

Corresponding author: Наханова Ж.К., Рефералл центр, Национальный научный центр материнства и детства корпоративного фонда «UMC». Адрес: ул. Туран 32, Астана, Казахстан. Телефон: 87013840017, 8(7172) 704547, 704560 (внут 1506). E-mail: Zhupar. Nahanova@umc.org.kz

\section{ABSTRACT}

The purpose of the medical examination of pupils of the orphanages and organizations providing education to orphan children and children deprived of the custody of parents was the assessment of the incidence of diseases and determination of possible ways of further rehabilitation. groups

Key words: morbidity of children, children's shelter, prophylaxis of children, health

\section{ТҰЖЫРЫМДАМА}

ЖЕКЕЛЕГЕН АЙМАҚТАР БОЙЫНША СӘБИ ҮЙЛЕРІ ЖӘНЕ БАЛАЛАР ҮЙЛЕРІ ТӘРБИЕЛЕНУШІЛЕРІНІН СЫРҚАТТАНУШЫЛЫҒЫ Наханова Ж.К.1, Қайырмұқанова Ш.Қ.1

${ }^{1}$ Рефералл орталығы, «UMC» корпоративтік қорының Ана мен бала ұлттық ғылыми орталығы, Астана, Қазақстан

${ }^{2}$ Педиатрия бөлмесі, «UMC» корпоративтік қорының Республикалық диагностикалық орталығы, Астана, Қазақстан

Медициналық тексеруден өткізудің мақсаты балалар үйлері және атааналарының қарауынсыз қалған, жетім балаларға арналған білім беру мекемелерінің тәрбиеленушілерінің сырқаттанушылығын анықтау және әрі қарай оңалтуды айқындау болып табылады.

Маңызды сөздер: балалардың сырқаттанушылығы, балалар үйі, балалардың диспасеризациясы, денсаулық топтары.

\section{PEЗЮME}

ЗАБОЛЕВАЕМОСТЬ ВОСПИТАННИКОВ ДЕТСКИХ ДОМОВ И ДОМОВ РЕБЕНКА ПО ОТДЕЛЬНЫМ РЕГИОНАМ

Наханова Ж.К. 1, Кайрмуханова Ш.К. 1

${ }^{1}$ Рефералл центр, Национальный научный центр материнства и детства корпоративного фонда «UMC», г. Астана, Казахстан

${ }^{2}$ Отдел педиатрии, Республиканский диагностический центр корпоративного фонда «UMC», Астана, Казахстан

Целью проведения медицинского осмотра детей воспитанников домов ребенка и организаций образования для детей-сирот и детей, оставшихся без попечения родителей является выявление заболеваемости и определение путей дальнейшей реабилитации.

Ключевые слова: заболеваемость детей, детские дома, диспансеризация детей, группы здоровья.

\section{Введение}

В настоящее время среда в учебно-воспитательных учреждениях рассматривается как динамическая многокомпонентная система, которая формируется под влиянием природно-климатических факторов, уровня коммунального благоустройства учреждения, степени его наполняемости детьми и др. [1.2].

Целью проведения медицинского осмотра детей воспитанников домов ребенка и организаций образования для детей-сирот и детей, оставшихся без попечения родителей является выявление заболеваемости и определение путей дальнейшей реабилитации.

Заболеваемость определена по результатам проведения медицинского осмотра детей воспитанников домов ребенка и организаций образования для детей-сирот и детей, оставшихся без попечения родителей согласно действующему приказу Министерства здравоохранения и социальной защиты Республики Казахстан от 29 декабря 2014 года №361 «О внесении изменения в приказ исполняющего обязанности Министерства здравоохранения Республики Казахстан от 10 ноября 2009 года №685 «Об утверждении Правил проведения профилактических медицинских осмотров целевых групп населения» [3].

Охвачены в основном Северо-Восточные регионы республики. Профосмотр проводился в 22 учреждениях, осмотрено 1056 детей. Из них в 1 группе здоровья - 183, во 2 и 3 группе - 873 детей.

Результаты осмотра в разрезе по областям:

По Карагандинской области было осмотрено всего 94 ребенка. Из них с патологией 92 детей со 2-й и 3-ей группой здоровья. Из них на диспансерный учет и реабилитацию взято 69 детей. 7 детей направлены на госпитализацию в 
стационары областного уровня. В верификации диагноза, коррекции в лечении на республиканском уровне нуждаются 2 детей.

По Кустанайской области было осмотрено всего 215 детей. Из них с патологией 213 ребенка со 2-й и 3-ей группой здоровья. На диспансерный учет и реабилитацию взято 46 детей, 12 детей направлены на госпитализацию в стационары областного уровня. В верификации диагноза, коррекции в лечении на республиканском уровне нуждаются 6 ребенка.

По Северо-Казахстанской области было осмотрено всего 239 ребенок. Из них с патологией 168 детей со 2-й и 3-ей группами здоровья. На диспансерный учет и реабилитацию взято 90 детей, нуждаются в госпитализации в стационары областного уровня 31 детей. В верификации диагноза, коррекции в лечении на республиканском уровне нуждаются 6 детей.

По Акмолинской области было осмотрено всего 150 детей. Из них с патологией 99 ребенка со 2-й и 3-ей группой здоровья. На диспансерный учет и реабилитацию взято 48 детей, 9 детей нуждаются в госпитализации в стационары областного уровня. В верификации диагноза, коррекции в лечении на республиканском уровне нуждаются 2 ребенка.

По Восточно-Казахстанской области было осмотрено 248 ребенка. Из них с патологией 197 детей со 2-й и 3-ей группой здоровья. На диспансерный учет и реабилитацию взято 109 детей, госпитализация в стационары областного уровня нуждаются 12 детей. В верификации диагноза, коррекции в лечении на республиканском уровне нуждаются 2 детей.

По Павлодарской области было осмотрено всего 110 детей. Из них с патологией 104 ребенка со 2-й и 3-ей группой здоровья. На диспансерный учет и реабилитацию взято 55 детей, на госпитализацию в стационары областного уровня направлены 2 детей. В верификации диагноза, коррекции в лечении на республиканском уровне не нуждаются.

В структуре заболеваемости по реультатам осмотра детей на 1 месте - заболевания глаз (в том числе врожденные пороки развития), на 2 месте - заболевания нервной системы (в том числе неврозоподобные энурезы), на 3 месте - заболевания сердечно- сосудистой системы, далее занимает заболевания органов дыхания и опорнодвигательного аппарата. Кроме того, определенную долю занимают различные пороки развития других систем и психические заболевания. Выявленные патологии требуют различных уровней обследования, лечения и дальнейшей реабилитации.

\section{Выводы}

Таким образом, в результате проведенного профилактического осмотра выявлена высокая заболеваемость детей, находящихся в детских домах и домах ребенка, которые нуждаются в разработке дальнейших путей реабилитации. Среди них некоторые дети нуждаются в получении высокоспециализированной помощи в республиканских центрах, что порой затруднительно по различным причинам, связанным с организацией предоставления медицинских услуг, требующих решения на местном уровне, на уровне областных и республиканских центров.

\section{TYЙIH}

Наханова Жұпар Кәрібекқызы, Қайырмұқанова Шолпан Қайнарбайқызы

Ана мен балаұлттықғылыми орталығы, Республикалық Диагностикалық Орталығы «University medical center» корпоративтік қоры, Астана, Қазақстан

Профилактикалық тексеру барысында сәби және балалар үйлеріндегі тәрбиеленушілердің сырқаттанушылығы жоғары екені анықталды, бұл әрі қарай оңалту жолдарын әзірлеуді қажет етеді. Араларында кейбір балалар республикалық орталықтарда жоғары мамандандырылған көмекті қажет етеді, кейде әртүрлі себептерге байланысты медициналық көмек көрсетуді ұйымдастыру барысында жергілікті, облыс және республикалық орталықтар деңгейінде шешуді талап ететін қиындықтар туындайды.

\section{RESUME}

Nakhanova Zhupar Karibekovna, Kairmukhanova Sholpan Kainarbaevna

Corporate fund "University Medical Center" National Research Center for Maternal and Child Health, Republic Diagnostic Centre, Astana, Kazakhstan

\section{INCIDENCE OF DISEASES AMONG THE PUPILS} OF ORPHANAGES IN DIFFERENT REGIONS

Therefore, as a result of the conducted investigation we discovered a high incidence of diseases among children in orphanages that require further ways of rehabilitation. Among them, there are children that require highly specialized care in republican center $\quad \mathrm{s}$ which is at times troublesome for different reasons connected to organization of the provision of care, which requires a solution at the level of local, regional and republican centers.

\section{Литература:}

1. Akhtyamova O.V. The state of health and the organization of medical care for social orphans in the homes of a child of a general type. The dis. On s.isk.chen.step. Cand. honey. sciences. Kazan, 2004; 220.

2. Filkina O.M. Features of the health of children who are brought up in orphanages. Collection of scientific works of Ivanovo. 1997; 340-344.

3. Order No. 361 of the Minister of Health and Social Protection of the Republic of Kazakhstan of December 29, 2014 "On Amending the Order of the Acting Minister of Health of the Republic of Kazakhstan of November 10, 2009, No.685" On Approval of the Rules for Conducting Preventive Medical Examinations of Target Populations. " 